Marketing in Asia Group

Asian Journal of Business Research

Volume 10 Issue 1, 2020

ISSN 2463-4522 e-ISSN 1778-8933

DOI: $10.14707 / a j b r .200072$

\title{
Editorial: It Will Go Away!? \\ Pandemic Crisis and Business in Asia
}

\author{
Hiram Ting \\ Faculty of Hospitality and Tourism Management, UCSI University, Malaysia \\ Ming Chuan University, Taoyuan, Taiwan \\ Jeffrey Ling ${ }^{1}$ \\ MNT Ventures Limited, New Zealand and REV by Venturecraft, Singapore \\ Jun Hwa Cheah \\ School of Business and Economics, Universiti Putra Malaysia, Malaysia
}

\begin{abstract}
In this Editorial we look into the lessons business in Asia can learn and certain opportunities academics and practitioners can tap into during the COVID-19 pandemic. We also look at some of the plausible things marketers and those who are going into business using online platforms can do during the crisis. Given the magnitude of the pandemic, business strategies and activities need to be reconsidered. Although the lessons and approaches presented in the Editorial are not entirely new, especially to those in digital marketing, business technology and innovation, they have to be evaluated and planned out in a new light. Despite the devastating effect of the crisis, it is hoped that the Editorial will shed some ideas and perpetuate the discourse about the moving forward of business in Asia at these times.
\end{abstract}

Keywords: Business in Asia, Marketing Crisis, Pandemic, COVID-19, Innovation

\footnotetext{
${ }^{1}$ Corresponding Author: Jeffrey Ling. He helps various tech startups with their cross-border scaling. He was in three startups, as well as assisted more than 150 startups while working for an incubator and later an accelerator. He can be contacted at lingdecklee@gmail.com.
}

Publication Details: Received 10 April 2020; Revised 15 April 2020; Accepted 18 April 2020 


\section{Introduction}

Here we are, stuck in the global pandemic of the century. The virus has not gone away yet. For the first time, people of the world are united or forced to accept decision to observe the restrictions put up by the governments and healthcare authorities to combat COVID-19. The world stops moving, literally. Stock markets nosedived. The worst recession ever is dawning. Someone described the current dark moment as akin to experiencing SARS, 9/11 and the global financial crisis simultaneously. Massive stimulus packages are already in place everywhere to help economies hunker down for the stormy economic winter to pass, albeit certain things will not return to normalcy after this pandemic is over and done with.

When writing the Editorial for this issue, we combined our observation of external events with our learning about business and specifically marketing in Asia. As an early view, what are some of the significant impacts this devastating crisis is bringing to the business world? What we have summarised below are not rocket science nor exhaustive; rather they are presented to generate further thoughts and invoke some healthy or scholarly debates. For those of us who see the glass as half full, what are the resulting new opportunities and how prepared are we for such opportunities? Like what we did in our past Editorial about ten marketing trends (Ting, Fam, Chan \& Cheah, 2019), below are the ten points pertaining to business opportunities (or threats) during and in the aftermath of the pandemic which we wish to put forward.

\section{Unprecedented Gravitation to Home-Based Economic Activities}

Social/physical distancing will likely become a recurring prerequisite one way or another going forward (Kim, Zhang, \& Li, 2008). Home is suddenly the centre of everyone's universe. The numbers associated with work-from-home, home learning, doorstep delivery, and home consumption of entertainment/content already experience a steep spike, with momentum unlikely to relent after the pandemic has passed. This is because the compelled mass experiments have validated things such as work-from-home for all staff or completing school education at home are not so unthinkable after all. The shifted attitude will further spur the proliferation of the under-appreciated technologies such as drones, robots, virtual reality and telemedicine (Wirtz \& Ehret, 2017; Wirtz, Patterson, Kunz, Gruber, Lu, Paluch, \& Martins, 2018). For example, can we imagine a new way of travel that does not entail transportation and accommodation?

\section{Vulnerability-Induced Home-Production and/or Stockpile of Strategic Resources}

The illicit actions of hoarding and intercepting valuable supplies we witnessed during the pandemic expose how governments are still ill-prepared for certain necessities in life during a worldwide crisis (Ang, Leong, \& Kotler, 2000). Going forward, the wealthy nations should mandate home-production and/or stockpile of water, food, medical supplies, agricultural supplies, and certain production raw materials and equipment. What will be intriguing is how each such nation strikes a balance between national security and wastage (Ang et al., 2000). In any case, fair to say those already in these lines of business are generally thriving now and should continue to be in high demand for a while. 


\section{A Wake-Up Call to Conventional Way of Doing Business}

The stringent virus containment measures mean organisations that derive customer demands from substantial frontline efforts now suddenly have their growth engine turned off for them. Those that have fully removed human touch from their business equation will survive better (Wirtz \& Ehret, 2017). Those that do not yet have a virtual presence will need to think hard and fast how to successfully implement the perhaps long-overdue digital transformation internally (Ehret \& Wirtz, 2017). For example, how can the sales staff continue to sign up new clients if they can no longer attend trade shows and conferences? Why would digital marketing make sense if the purpose is still to convert online traffic to foot traffic when people have already stopped going to your physical stores? Expect more innovation not in terms of technology, but also business models.

\section{Managing When You Can't See the Team}

Business students/graduates will probably need to take a grain of salt when talking about management best practices in the future. Although remote working is not novel, most of us have never experienced having every company member working remotely for an extended period of time. During lockdown or any form of movement restriction, things such as staff performance will need to be motivated, measured, and appraised very differently (Buchanan, Fitzgerald, Ketley, Gollop, Jones, Lamont, Neath, \& Whitby, 2005). Guidelines have to be rewritten and managers retrained. Although there are already a variety of online productivity tools around to ease the transition, most managers have not looked at or utilised them seriously enough, needless to say construct a holistic management system on top of them (Johnson, Lukaszewski, \& Stone, 2016). Time will tell if managers can manage chaos and avoid being the chaos itself.

\section{Rethink the Manufacturing and Supply Chain Sectors}

Globalisation has done wonders to the value chain of various industries that the interconnected world economy has taken for granted for a few decades, but also makes it susceptible to macroeconomic factors. When the pandemic forces the abrupt closure of national borders, factories in each country cannot achieve full production scale because parts and components are unable to be shipped in from abroad. This puts in question the logic behind the dependence countless countries currently placed on their trading partners. Going forward, economic efficiency maximisation may take a back seat, and along with it things like 'comparative advantage' and 'just-in-time production'. Instead, manufacturers may opt for a production mode that is entirely local-sourced (Berti \& Mulligan, 2016). For certain countries, this means jobs will be replaced and/or the cost of goods will inflate.

\section{Golden Opportunity for China to Rewrite Its 'World's Factory' Label?}

Before the pandemic, the escalating labour cost is already driving more and more foreign companies in China to shift their production elsewhere. The pandemic is likely to do nothing less than hastens the inevitable exodus. Right now, the two economic superpowers Japan and the US are making plans to ease the repatriation of their own companies out of China. Being the largest exporter of the world, will China 
experience an economic setback from the resulting unemployment and the associated social issues, or will it be able to evolve and remain a thriving economy without the same reliance on manufacturing and export sectors as was previously the case?

\section{Finding the Constant amidst the Changing Employment Landscape}

The tsunami of lockdowns imposed in different countries is proving disastrous to the tourism, hospitality and retail sectors, with the wrath quickly rippling across to other sectors (Cefis \& Marsili, 2019). Involuntary downsizing is claiming its toll as swiftly as the virus itself. Cash-poor businesses are being pulverised and some are impossible to make a post-pandemic comeback. Twenty-two million (it was ten million when we drafted the Editorial a week ago) workers are already alarmingly jobless in the US alone. Those who are adaptable will shift service to more resilient sectors (rise in demand for public servant jobs perhaps?) while those who are less adaptable require government intervention. One thing for sure is that digital workers will have once again proven themselves to be ever more desirable in times of crisis.

\section{One's Loss Is Someone Else's Gain?}

With so many businesses strapped for cash and unable to survive for more than 3 to 6 months, those that are currently cash-rich are just getting ready to swoop in to cherrypick to their own delight (Cefis \& Marsili, 2019). Do expect an increase in merger and acquisition talks (Wann \& Lamb, 2016), with the sell side at the mercy of the busy side. Those who are fundraising will find themselves in a poor bargaining position or consider themselves lucky if they can even line up a few investor meetings. At the end of the day, the wealthy will inevitably get wealthier, all things considered.

\section{Coping With Anxieties and Uncertainties}

The entire crisis will be a traumatic experience to a substantial part of the world population. The sudden loss of loved ones to the illness and/or the prolonged financial hardship can be overwhelming to the survivors. The burgeoning of fake news and the spreading of inaccurate or biased information, despite being warned and traced by the authorities, as well as mercenaries and wolves in sheep's clothing further compound the problems (Tandoc Jr, Lim, \& Ling, 2018). Uncertainties become the norm as anything from macro to micro scales can change, and change immediately. As such, the need for counselling and guidance may become more essential. Some may find this surprising, but this difficult time is also the time for the mental health professions, spiritual or religious entities and the associated innovation to grow their respective importance (Asmundson \& Taylor, 2020).

\section{Satellite Images Show Earth Is Healing, But Will It Last?}

Amidst this crisis, one encouraging news is that the plaguing pollution issues have enjoyed a major relief in the past three months due to massively-curtailed economic activities. Here is unequivocal evidence that unbridled economic activities are detrimental to Mother Nature. Then again, is such unplanned relief sustainable? When the lockdowns or restrictions are lifted, will the nasty emission make a comeback? After all, without economic activities, mankind will be without means to make ends 
meet. It is imminent that mankind can continue to discover ways to emulate the same positive environmental benefits enjoyed now without going back to the old ways of industrial and transportation activities (Ness \& Xing, 2017). This pandemic has taught us many lessons but will we learn from them, especially when we are accustomed to convenience and good lives again?

The aforementioned might not sound new to some. It is simply because history has never failed to repeat itself. Despite how much we have studied the past, it is still unfeasible to prepare for all vicissitudes. Who would have predicted at the beginning that social distancing is the best way, even the only way, to contain the spread? But to what degree and for how long are debatable when economic development is at stake. Notwithstanding ignorance and delays in actions, when faced with surmounting adversities, mankind has proven to be resilient and resourceful, especially when they come together in unison. Each past crisis did come with its own silver lining. Learn the lessons and prepare better next time, not just to politicians, financial gurus, health experts and techpreneurs, but also to academics and business practitioners.

\section{Final Thoughts: Is Marketing in Crisis?}

Narrowing down to marketing, the current pandemic has been a great challenge to marketers. Many consumers have shifted (or have been shifting) their focus and the manner they live and work to better manage themselves, and their priorities (Balis, 2020). Social distancing, which is imposed in almost every country, has created a major shift in behavioural trends (Kim et al., 2008). The fear towards the deadly virus and the spreading of news, be it factual or fake, have resulted in mental distress, panic buying, compulsive hoarding and other abnormal behaviours (Lim, Cheah, Cham, Ting, \& Memon, 2020; Zhen, Shou, \& Yang, 2020). Pragmatic practices and arrangements, such as no handshakes, wearing face masks, online teaching, washing hands regularly, the number of people gathered in a confined area, food handling, travel bans, and only the head or one person of a family allowed to leave home and buy essentials, have not only affected consumers' behaviour in times of the pandemic, but will likely also have a profound impact on their future behaviour when the pandemic is over. COVID-19 is a global crisis. Is marketing in crisis as well?

According to Clark (1988), "Marketing Crisis" is described as a situation where marketing decision makers have a very short time to respond to something which seriously threatens marketing goals and reduces their ability to manage the transaction in the marketplace. As such, marketers need to reconsider their marketing strategies, tactics and activities, and they have to do it swiftly but prudently during the pandemic in order to come out with an effective response to meet consumers' needs, values and acquisition-consumption-disposition patterns (Ting, Thaicon, Chuah, \& Tan, 2019). Although it is futile to make a generalized presumption about consumer behaviour in Asia in times of abnormality, and as we are still unsure how the "new normal" may look like at the latter stage of and after the crisis, we like to briefly describe five marketing-related points not only for marketers' considerations but also those who are already in business or plan to go into business using online platforms. These points could also be useful as directions of future investigations. 
Firstly, present the product and service with empathy and transparency. When consumers feel vulnerable and are confused during the pandemic time, it is prudent to present the brand with empathy and transparency (Alhouti, Johnson, \& Holloway, 2016). Consumers generally accept that most businesses are in trouble at this time, and they may be more willing to tolerate minor mistakes or delays. However, not being understanding and transparent, as seen in the briefings or updates by certain government officials about how they contain the virus, are detested. Secondly, use media and messages in agile ways (Andzulis, Panagopoulos, \& Rapp, 2012). To quickly pivot creative messages, it is imperative that marketers build more rapidresponse operating models internally and with agencies. Nike, for example, adopting a new message: "Play inside, play for the world" and McDonald pulling apart its iconic golden arches in a picture with the message: "I'm already home" are some of the initiatives to promote social distancing and show a commitment to public safety. Thirdly, associate the brand with good (Hur, Kim, \& Woo, 2014). Consumers will remember brands for their acts of good in a time of crisis, particularly if done with true heart and generosity. They could in a physical form, such as donation of hand creams and giving face masks to the healthcare personnel or the needy ones, or in a psychological form, such as sharing feel-good contents that alleviate anxiety and promote positive reaction towards the crisis. Fourthly, adapt to new ways of selling product and delivering services (Andzulis et al., 2012). Companies are adapting to the environmental changes at different degrees and those which are less digital-savvy begin to use online platforms more. Although digital and social media marketing is not new, the present crisis forces and even encourages more to adopt online platforms to do business and connect to their customers, such as indoor exercise, learning from an instructor how to cook a certain dish at home and having virtual club nights.

The present pandemic will surely go down in history as a defining moment for local or international businesses in Asia. Such a cataclysmic event will have a profound effect on how consumers behave and interact for a long time. While the loss of life, the closing down of business and the tensions between individuals, organisations and countries are unfortunate, the pandemic crisis could well be a huge factor and precursor to creative economy, labour-saving technology and disruptive innovation. Whatever the future holds, COVID-19 has taught the business world to never belittle something as small as a virus. Ironically, "it will go away" is at best a premature claim, and is at worst an ignorant delusion. The ordeal has also made it extremely clear that the community, the nation and even the world can only overcome this pandemic if they put aside their interests and operate as one unified force, a principle or value which many business organisations need to be reminded and re-learn.

\section{References}

Alhouti, S., Johnson, C. M., \& Holloway, B. B., (2016), "Corporate social responsibility authenticity: Investigating its antecedents and outcomes", Journal of Business Research, vol. 69, no. 3, pp. 1242-1249.

Andzulis, J. M., Panagopoulos, N. G., \& Rapp, A., (2012), "A review of social media and implications for the sales process", Journal of Personal Selling \& Sales Management, vol. 32, no. 3, pp. 305-316.

Ang, S. H., Leong, S. M., \& Kotler, P., (2000), "The Asian apocalypse: Crisis marketing for consumers and businesses", Long Range Planning, vol. 33, no. 1, pp. 97-119.

Asmundson, G. J., \& Taylor, S., (2020), "Coronaphobia: Fear and the 2019-nCoV outbreak", Journal of Anxiety Disorders, vol. 70, pp. 1-4. 
Balis, J., (2020), "Brand marketing through the coronavirus crisis", Retrieved from https://hbr.org/2020/04/brand-marketing-through-the-coronavirus-crisis

Berti, G., \& Mulligan, C., (2016), "Competitiveness of small farms and innovative food supply chains: The role of food hubs in creating sustainable regional and local food systems", Sustainability, vol. 8, no. 7, pp. 1-31.

Buchanan, D., Fitzgerald, L., Ketley, D., Gollop, R., Jones, J. L., Lamont, S. S., Neath, A., \& Whitby, E., (2005), "No going back: A review of the literature on sustaining organizational change", International Journal of Management Reviews, vol. 7, no. 3, pp. 189-205.

Cefis, E., \& Marsili, O., (2019), "Good times, bad times: innovation and survival over the business cycle", Industrial and Corporate Change, vol. 28, no. 3, pp. 565-587.

Clark, T., (1988), "The concept of a marketing crisis", Journal of the Academy of Marketing Science, vol. 16, no. 2, pp. 43-48.

Ehret, M., \& Wirtz, J., (2017), "Unlocking value from machines: Business models and the industrial internet of things", Journal of Marketing Management, vol. 33, no. 1-2, pp. 111-130.

Hur, W. M., Kim, H., \& Woo, J., (2014), "How CSR leads to corporate brand equity: Mediating mechanisms of corporate brand credibility and reputation", Journal of Business Ethics, vol. 125, no. 1, pp. 75-86.

Johnson, R. D., Lukaszewski, K. M., \& Stone, D. L., (2016), "The evolution of the field of human resource information systems: Co-evolution of technology and HR processes", Communications of the Association for Information Systems, vol. 38, no. 1, pp. 533553.

Kim, K., Zhang, M., \& Li, X., (2008), "Effects of temporal and social distance on consumer evaluations", Journal of Consumer Research, vol. 35, no. 4, pp. 706-713.

Lim, X., Cheah, J., Cham, T., Ting, H., \& Memon, M., (2020), "Compulsive buying of branded apparel, its antecedents, and the mediating role of brand attachment", Asia Pacific Journal of Marketing and Logistics, in press.

Ness, D. A., \& Xing, K., (2017), "Toward a resource-efficient built environment: A literature review and conceptual model", Journal of Industrial Ecology, vol. 21, no. 3, pp. 572592.

Tandoc Jr, E. C., Lim, Z. W., \& Ling, R., (2018), "Defining "fake news": A typology of scholarly definitions", Digital Journalism, vol. 6, no. 2, pp. 137-153.

Ting, H., Fam, K. S., Chan, Y. W., \& Cheah, J. H., (2019), "Editorial - Ten trends shaping the future of marketing: Considerations for the academics", Asian Journal of Business Research, vol. 9, no. 1, pp. I-IX.

Ting, H., Thaichon, P., Chuah, F., \& Tan, S. R., (2019), "Consumer behaviour and disposition decisions: The why and how of smartphone disposition", Journal of Retailing and Consumer Services, vol. 51, pp. 212-220.

Wann, C., \& Lamb, N. H., (2016), "Are investor reactions to mergers and acquisitions dependent upon the economic cycle?", Journal of Accounting and Finance, vol. 16, no. 6, pp. 1-15.

Wirtz, J., \& Ehret, M., (2017), "Capturing value in the service economy", Journal of Service Management Research, vol. 1, no. 1, pp. 22-38.

Wirtz, J., Patterson, P. G., Kunz, W. H., Gruber, T., Lu, V. N., Paluch, S., \& Martins, A., (2018), "Brave new world: Service robots in the frontline", Journal of Service Management, vol. 29, no. 5, pp. 907-931.

Zheng, R., Shou, B., \& Yang, J., (2020), "Supply disruption management under consumer panic buying and social learning effects", Omega, in press. 